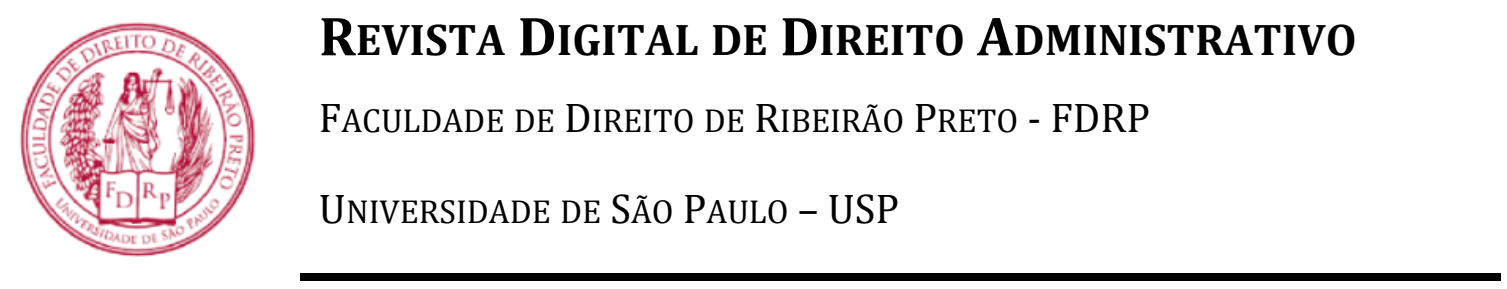

Seção: Artigos Científicos

Notas sobre a história das prisões do Estado de São Paulo

Notes on the history of prisons in the State of São Paulo

\begin{abstract}
Liliane Klein Garcia
Resumo: 0 presente artigo busca produzir uma curta compilação da história da execução da pena de prisão em estabelecimentos no território do atual estado de São Paulo, ressaltando acontecimentos que alteraram a forma com a qual o governo e a sociedade pensam o ato de punir e as formas aceitáveis de o fazer. São pontuadas evoluções administrativas e da atenção ao detento desde o período colonial, passando pelo Império e pela República, ressaltando a tendência circular de períodos de humanização e recrudescimento da política penitenciária. Conclui-se que o atual momento político no estado favorece uma mudança do paradigma presente desde 2007.
\end{abstract}

Palavras-chave: Execução penal, administração penitenciária, humanização

\begin{abstract}
This article seeks to briefly compilate the history on the penal executions in establishments throughout the current territory comprising the state of São Paulo, highlighting occurrences, which altered the way the state government and Society think about the act of punishing and the acceptable manners of doing so. Administrative evolutions and detainee care are characterized throughout the colonial era, the imperial period and the republic, with special attention to a circular tendency of humanization and hardening of penal policy. It is concluded that the current political moment favors a change in paradigm, which has established itself in 2007.
\end{abstract}

Keywords: Penal Execution, Prison Administration, Humanization.

Disponível no URL: www.revistas.usp.br/rdda

DOI: http://dx.doi.org/10.11606/issn.2319-0558.v7n2p170-193

Este conteúdo está protegido pela lei de direitos autorais. É permitida a reprodução, desde que indicada a fonte como "Conteúdo da Revista Digital de Direito Administrativo". A RDDA constitui periódico científico da FDRP/USP, cuja função é divulgar gratuitamente pesquisa na área de direito administrativo. Editor responsável: Professor Associado Thiago Marrara. 


\title{
NOTAS SOBRE A HISTÓRIA DAS PRISÕES DO ESTADO DE SÃO PAULO
}

\author{
Liliane Klein GARCIA*
}

Sumário: 1 Introdução; 2 Colônia, Império e República Velha; 3 Estado Novo, República Liberal e Ditadura Militar; 40 Massacre do Carandiru; 5 Crime Organizado, Secretaria da Administração Penitenciária e o Século XXI; 6 Conclusão; 7 Referências bibliográficas

\section{Introdução}

Desde que há ética, um comportamento modelar, há antiética, tudo aquilo que não se encaixa no que é considerado correto. De modo a manter a ordem, estimular os indivíduos a perseguir o bom comportamento e extirpar os sentimentos de vingança e culpa da sociedade, existe a justiça penal, guardadas as devidas proporções ao nível de desenvolvimento de cada agrupamento humano.

Michel Foucault (2014), em seu livro Vigiar e Punir, demonstra e argumenta sobre o nascimento e a evolução sociológica e filosófica da justiça penal, em especial do ato de punir, nas sociedades. Tal observação é necessária, pois o tratamento dos infratores diz muito sobre os valores essenciais dos grupos humanos, e poucos estudos são conduzidos no estado sobre o assunto.

O texto foucaltiano desafia o pressuposto de que a cadeia é uma forma inerentemente mais humana de punição. Parafraseando o comediante John Oliver (LETHAL, 2019), justiça penal é inerentemente inumana, e toda forma de humanização é ao benefício da consciência coletiva da sociedade que a impõe.

Enquanto o trabalho não partilha dessa ideia, será demonstrado que o sistema prisional paulista foi, e ainda é, um grande violador de direitos humanos básicos das populações encarceradas, das suas famílias e mesmo dos funcionários que o mantém.

Ao demonstrar tal fato, o artigo objetiva fomentar reflexões sobre a execução penal em São Paulo, bem como os ciclos de humanização e recrudescimento que marcaram a história das prisões do estado.

De modo a tornar a empresa mais pedagógica, foi feita uma divisão temporal razoavelmente arbitrária, da colonização à década de 1930, depois até a década de 1980, e de então até a atualidade, com cortes em pontos em que há grande mudança institucional no sistema administrativo.

\footnotetext{
* Bacharel em relações internacionais pela UNESP e em ciências econômicas pela Universidade de Franca. Especialista em direito internacional pela Universidade Cruzeiro do Sul.
} 
Houve também uma higienização e organização dos eventos, de modo a encaixá-los nesses espaços temporais, que nem sempre refletem a completa realidade da administração penal. Até a fundação da Secretaria de Administração Penitenciária em 1993, os diretores de cada unidade eram largamente independentes, e a realidade de uma poderia ser amplamente diferente de outra, constituindo a necessidade de uma generalização em torno do Complexo do Carandiru, que, até a virada do século, concentrava a maioria dos detentos do estado.

\section{Colônia, Império e República Velha}

A história dos presídios de São Paulo é tão antiga quanto a própria história dos assentamentos coloniais no território do atual estado. A atual capital foi fundada em 1554 pelos jesuítas e reconhecida como vila, ou seja, dotada de administração local, em 1560, a única no interior do Brasil. Em 22 de março de 1681, o donatário de São Vicente, o Marquês de Cascais, transfere a capital do litoral para São Paulo (NEVES, 2007, p. 18).

Nesses tempos, a manutenção da ordem pública era exercida pelos "somaneiros", de somana, grafia antiga de semana, que eram homens voluntários revezados semanalmente e patrulhavam as ruas da vila, retirando do convívio social os que perturbavam a paz. Todavia, as condições da cadeia eram tão precárias que não serviam ao propósito repressivo: não havia restrição de visitantes ou movimento para dentro ou fora do edifício, não havia portões e grilhões, não havia vigilância, disciplina, e mesmo a cobrança de multas era falha (BELMONTE, 1934, p. 134135).

Outro problema crônico do sistema penitenciário paulistano durante o período colonial foi o de pessoal. Apesar de ser uma função bem-remunerada, em oposição aos somaneiros, que não recebiam nada, raramente a cidade conseguia encontrar alguém disposto a assumir o cargo de carcereiro, em razão de, em caso de fuga, o responsável pela cadeia ou recapturava o fugitivo, ou era ele mesmo preso (RODRIGUES, 2011, p. 7).

A cadeia era localizada junto ao Colégio de São Paulo, onde congregavam todos os poderes administrativos da cidade. Isso era usual na sociedade colonial brasileira, a existência da chamada Casa de Câmara e Cadeia. Na maioria dos municípios, a separação se deu na Independência, já que, com a Constituição de 1824, com o Código Criminal de 1830 e o Ato Adicional de 1834, a autoridade local perde poderes em favor dos governos provinciais, e os tribunais, as cadeias e as milícias passam a ser abrigadas em prédios distintos.

A primeira cadeia pública de São Paulo construída em alvenaria estava localizado na Praça João Mendes, e foi viabilizado através de contribuições dos munícipes a partir de 1787. Para lá, mudam-se as autoridades municipais, enquanto no Colégio 
de São Paulo passa a funcionar o governo provincial (VIEIRA; SILVA, 1955, p. 105110).

A primeira grande revolução no sentido de humanização do sistema de administração de penas no Brasil foi pela Constituição de 1824 e o Código Criminal de 1830, que proibiam as penas cruéis (açoites, tortura, marca a ferro, entre outras) aos homens livres. Em seu lugar, além da prisão simples e da com trabalhos forçados, havia as penas de morte, galé (execução de serviço público), desterro, multa e a destituição de cargos estatais (RODRIGUES, 2011, p. 9-10).

É importante pontuar que esse avanço era limitado aos homens livres. Ainda era facultado aos senhores de escravos praticar esses atos contra seu plantel, bem como de incumbir as autoridades públicas de fazê-lo. Inclusive, era prática comum enviar escravos para as cadeias públicas para que fossem castigados (RODRIGUES, 2011, p. 6-7).

Com o ciclo do café e o desenvolvimento urbano da cidade de São Paulo a partir da metade do século XIX, houve a necessidade da construção de uma unidade prisional maior do que a cadeia pública na Praça João Mendes e, com isso, surgiram novas demandas na administração penitenciária.

Nesse contexto, o governo provincial inaugura em 1852 a Casa de Detenção de São Paulo, localizada no bairro do Bom Retiro. Os 160 detentos, em sua capacidade máxima, estariam submetidos ao sistema auburniano (RODRIGUES, 2011, p. 10-11).

A preocupação da Casa de Detenção era, notadamente, o preparo do interno para o retorno ao convívio social, a notar pelo ensino de ofícios. 0 lugar também oferecia melhores condições de vida, com elevados padrões de higiene, estrutura física e organizacional, se comparados aos padrões das demais cadeias públicas da província (RODRIGUES, 2001, p. 9).

$\mathrm{Na}$ administração da instituição, o poder centrava-se na figura do diretor. 0 rumo de cada um dos aspectos da Casa de Correção, sua eficiência, dependia da vontade e virtudes de quem ocupava o cargo de chefia (SALLA, 1999, p. 103).

É de se ressaltar que o cargo de diretor da Casa de Correção, em sucessivas gestões, foi ocupado por pessoas de reconhecido prestígio na sociedade paulistana, na verdade pessoas com profundo conhecimento dos assuntos penitenciários. Isso se depreende dos relatórios deixados por eles, expondo seus pontos de vista com relação aos sistemas penitenciários àquela época em debate: sistema pensilvânico e sistema auburniano (RODRIGUES, 2011, p. 10).

O sistema pensilvânico tinha suas origens, naturalmente, na Pensilvânia, mais precisamente na Penitenciária de Cherry Hill, na Filadélfia, uma das primeiras penitenciárias no modelo moderno (JESUS FILHO, 2017, p. 69). 0 modelo correcional consistia no total isolamento em celas individuais, na obrigação estrita do 
silêncio, na abstinência total de bebidas alcoólicas, na meditação e oração. A única leitura permitida é a da Bíblia. 0 isolamento total impede a promiscuidade e enseja a meditação, mas a extrema rigidez desse sistema provoca distúrbios psicóticos que podem levar à loucura. 0 que se buscava era um sistema que, além de melhorar as condições da prisão, possibilitasse a recuperação do preso, e, neste aspecto, mostrou resultado insatisfatório (RODRIGUES, 2011, p. 7-8).

O sistema auburniano, que deve seu nome à Penitenciária de Auburn, em Nova Iorque, construída em 1816 (JESUS FILHO, 2017, p. 69), surgiu da necessidade de superar as limitações do sistema pensilvânico. Esse sistema adota como pedra angular o trabalho em comum fora da cela, como agente de transformação e de reforma do preso. Ele considera que quando o recluso se dedica a uma atividade laboral de maneira disciplinada e ordeira na prisão é indício de que ele busca a reabilitação. Esse modelo mantém, todavia, a regra do silêncio absoluto e do recolhimento celular noturno, impossibilitando aos presos qualquer comunicação entre si (RODRIGUES, 2011, p. 8).

O viés econômico que caracterizava o sistema auburniano foi o motivo da sua adoção pelos Estados Unidos, enquanto a Europa, que naquele período não necessitava do trabalho prisional, optou pelo sistema pensilvânico. Ambos os sistemas possuem, entretanto, caráter predominantemente punitivo e retributivo da pena (RODRIGUES, 2011, p. 8).

Do ponto de vista organizacional, a Casa de Correção mantinha uma estrutura bem simples, se comparada com as que são encontradas hoje em grande parte do mundo ocidental. A equipe era composta pelo diretor, um escrivão, um almoxarife, um enfermeiro, um médico e um capelão. Um mestre, contratado precariamente, coordenava as oficinas, que eram assumidas inteiramente por presos ou guardas, estes também eram contratados a título precário (JESUS FILHO, 2017, p. 36). O único funcionário contratado de forma permanente era o responsável pelas oficinas de encadernação (RODRIGUES, 2011, p. 9).

Um exemplo de como o diretor assumia uma posição extremamente centralizadora, controladora e decisiva na vida dos presos pode ser nomeado quando eles tentavam obter do Imperador o perdão de parte da pena que ainda restava cumprir, que era uma das atribuições do Poder Moderador na Constituição de 1824. Em alguns documentos, o diretor simplesmente remete os pedidos para o presidente da província que, por sua vez, deveria encaminhá-los ao monarca. Porém, em outros pode ser encontrado um "parecer", um favorecimento, do diretor sobre o preso que pede o benefício (SALLA, 1999, p. 104).

O controle da população carcerária era objeto de disputas entre as diferentes posições manifestadas pelo diretor, pelo chefe de polícia e pelo juiz municipal. Essa disputa pelo controle se materializava especialmente nas transferências para a Cadeia Pública, considerada como uma progressão. Por vezes o diretor buscava 
impedir a execução das ordens judiciais de transferência de presos recorrendo ao Presidente da Província (JESUS FILHO, 2017, p. 36).

Como já se expôs acima, a Casa de Correção adotava o sistema auburniano, cuja eficiência era posta em dúvida, dentre outros por Manoel Dias de Toledo, diretor da Casa por três anos, que era mais receptivo à disciplina rígida do sistema pensilvânico. Por outro lado, Francisco Antonio de Oliveira, diretor da Casa por quase vinte anos, via eficiência do sistema auburniano, e demonstrava isso com os baixos índices de reincidência, repudiando a prática do isolamento absoluto (RODRIGUES, 2011, p. 10).

As críticas e os elogios a um ou a outro sistema foram expostos em relatórios que consubstanciam argumentos reveladores de elevado saber jurídico e atualização com os temas em debate, à época, na Europa e Estados Unidos. Os diretores acima citados foram, ambos, professores da Faculdade de Direito de São Paulo (RODRIGUES, 2011, p. 10).

Os diretores se sucediam, tendo cada um optado e defendido um desses sistemas. Ao final, prevaleceu o sistema progressivo, o qual perdura até hoje na execução das penas, principalmente a partir da República (FERNANDES, 2000, p. 47-48). 0 sistema consiste, basicamente, em permitir a execução da pena através de dois ou mais estágios. Inicia-se pelo regime mais rigoroso e, de acordo com a boa conduta, com o merecimento demonstrado pelo sentenciado, passa-se, sucessivamente, para um regime mais brando, possibilitando, assim, o retorno do preso ao convívio social antes mesmo do término do tempo da condenação (RODRIGUES, 2011, p. 8).

Com a República, e o novo Código Penal de 1890, estabelecia-se a necessidade de oferecer condições mais dignas de encarceramento. Extinguiu-se a distinção das penas para segmentos diferentes da população, tendo em vista a abolição da escravatura, bem como das penas de morte, de galé e a perpétua: a pena privativa de liberdade não poderia exceder trinta anos (RODRIGUES, 2011, p. 11).

Nos primeiros tempos da República, o conceito de trabalho, antes concebido como algo degradante, ganhava outro significado, era tido como dignificante, honesto, fonte de virtude, de honradez. A mudança de paradigma serve para legitimar os meios de controle social desenvolvidos visando àqueles que não se adequavam à disciplina do trabalho: os vadios, os criminosos, mendigos e loucos (SALLA, 1999, p. 187).

De modo a responder às novas exigências relacionadas à administração da justiça, em 1906, o então governador Washington Luiz entrega a Ramos de Azevedo a tarefa de desenhar e construir uma nova instituição prisional (JESUS FILHO, 2017, p. 36-37).

Além dela, foram construídos também o Hospício do Juqueri (em Juqueri, atual Franco da Rocha, inaugurado em 1895 e reformulado em 1929, recebia os doentes 
mentais da capital), o Instituto Disciplinar (constituído, a partir de 1902, em vários municípios, recebia menores infratores e abandonados) e a Colônia Correcional (também presente em vários municípios, principalmente no interior, focava-se em trabalhos agrícolas), todos administrados independentemente uns dos outros, assim predominando em uns a imposição do controle médico sobre os indivíduos, noutros a vigilância e a repressão (SALLA, 1999, p. 187).

É importante pontuar que, até então, na maior parte dos municípios do interior do estado, não havia nenhuma instituição correcional. Os presos cumpriam pena ou em instalações tidas como provisórias, as cadeias públicas, ou eram enviados para São Paulo.

A partir de 1902, algumas cidades passaram a contar com presídios, e aqui se destaca principalmente Taubaté e Tremembé, no Vale do Paraíba. Taubaté passaria a abrigar uma Colônia Correcional, um Instituto Disciplinar e, posteriormente, uma penitenciária de segurança máxima. No final da década de 1920, essa última era transferida para a Ilha Anchieta, no município vizinho de Ubatuba, mas sua administração continuava no vale. Tremembé, ao lado, recebeu também uma Colônia Correcional, edifício ainda em operação.

Hoje, Tremembé possui o maior número de presídios de qualquer município paulista, cinco (duas masculinas, duas femininas e um centro de progressão), enquanto Taubaté possui um centro de detenção provisória, num prédio continuamente ocupado desde a virada do século XX.

Antes da inauguração da instituição, o governo do estado aprovou o Regimento Penitenciário do Estado, a Lei no 1.406 de 1913. Por este regimento, o controle sobre o destino dos presos é mantido principalmente na esfera administrativa. Ao diretor cabia presidir o "Tribunal do Comportamento", pelo qual classificava os presos segundo o seu comportamento, bem como encaminhar parecer ao Presidente do Estado, recomendando o livramento condicional dos presos (JESUS FILHO, 2017, p. 37).

É importante destacar que, revertendo as tendências administrativas do Império, a República Velha e a Constituição de 1891 concediam amplos poderes administrativos aos estados, incluindo o indulto.

Finalmente, em 1920, foi inaugurada a Casa de Detenção de São Pulo, o Presídio do Carandiru. A data é um marco muito importante: as experiências ocorridas lá dentro, tanto as bem-sucedidas quanto os desastres, moldaram a administração prisional do estado durante toda a sua existência.

A penitenciária era dotada de celas individuais, medindo $2,5 \mathrm{~m}$ por 4,0m, com 1.200 vagas. Atendia aos requisitos de salubridade (higiene, ventilação e iluminação) e segurança, constituindo-se no que havia de mais avançado na época em matéria de estabelecimento penitenciário (RODRIGUES, 2011, p. 11). 
Com a inauguração da Casa de Detenção, passa a existir uma estrutura administrativa com papeis definidos: uma diretoria, uma tesouraria, um almoxarifado, contadoria, expediente, seção de medicina e criminologia, seções de instrução, penal, industrial e avulsos. 0 diretor deveria residir no estabelecimento e a ele eram dados amplos poderes. Era o responsável por decidir sobre praticamente todas as atividades: higiene, disciplina, polícia e finanças do estabelecimento (JESUS FILHO, 2017, p. 37).

Além disso, poderia contratar e demitir livremente os empregados penitenciários, exceto para os cargos técnicos, como tesoureiro, médico, contador e almoxarife, que eram nomeados pelo presidente do estado. Ele inclusive poderia solicitar dos empregados trabalhar durante os fins de semana e feriados, instaurar processo administrativo e aplicar sanções disciplinares. (JESUS FILHO, 2017, p. 37-38).

Embora já se vislumbre um processo crescente de burocratização e uniformização na condução do cotidiano prisional, com vistas a reduzir o arbítrio, os poderes do diretor sobre os detentos continuavam quase feudais (JESUS FILHO, 2017, p. 38).

A Penitenciária do Estado foi considerada um padrão de excelência, nas suas primeiras décadas foi motivo de orgulho para os governantes locais, atraindo a visita de políticos, estudantes, autoridades acadêmicas e até mesmo personalidades como Claude Lévi-Strauss, que vinham a São Paulo para visitá-la. Era aberta à visitação pública e chegou a ser considerada um dos cartões postais da cidade de São Paulo (SALLA, 1999, p. 187).

A análise dos prontuários dos presos, todavia, revela uma instituição que apresentava todos os vícios presentes nas prisões comuns do país, apesar da popularidade da Penitenciária do Estado: um cotidiano tenso, cheio de conflitos e injustiças. Algumas ações banais, atos com os quais os presos procuravam combater o tédio, resultavam em punições (SALLA, 1999, p. 219).

As estatísticas demonstram, ainda, que eram poucos os casos de presos de origem social elevada, configurando a Penitenciária como um local de pobreza (SALLA, 1999, p. 219).

Em 1927, é organizada a Secretaria de Justiça e Segurança Pública, sob a qual foram colocados a penitenciária, os institutos disciplinares e o instituto correcional, a cadeia pública, a cargo da polícia civil (JESUS FILHO, 2017, p. 38-39).

Novas mudanças institucionais na organização da estrutura administrativa do sistema penal paulista foram temporariamente freadas aqui. Com o choque de 1929 e a decorrente desordem político-econômica, pouco se avançou em quaisquer pastas do governo local.

O presidente da república, Washington Luiz, a ser sucedido em 1930, se recusou a nomear o presidente do estado de Minas Gerais, o vice-presidente (também minei- 
ro) ou um nome neutro (no caso, Getúlio Vargas, do Rio Grande do Sul), causando a revolta desses dois estados, mais a Paraíba, contra o governo federal, São Paulo e os demais estados.

Apesar da clara vantagem dos paulistas, Washington Luiz foi deposto num golpe militar tenentista, eliminando as chances de resistência. Depois de quarenta e um anos, a República Velha chegava ao seu fim.

\section{Estado Novo, República Liberal e Ditadura Militar}

Assumindo o governo do país, Getúlio Vargas remove todos os presidentes de estado, a maioria deles opositores, e nomeia em seu lugar interventores que respondiam diretamente a ele. Também houve a cassação da maior parte das prerrogativas desfrutadas pelos estados durante a República Velha, centralizando funções administrativas nas mãos das autoridades federais.

Em 1937, Getúlio Vargas cria em São Paulo, assim como em outras partes do país, o Presídio Político para abrigar os detidos por razões de ordem política e social. No ano seguinte, em 1938, o Presídio Político é extinto e os detentos são distribuídos entre Carandiru, o Presídio Tiradentes e a Ilha Anchieta (JESUS FILHO, 2017, p. 39).

Em 1943, foi instituído o Departamento de Presídios do Estado, vinculado à Secretaria de Justiça e Segurança Pública, reunindo todos os presídios do estado: a Penitenciária do Estado e o Presídio de Mulheres de Sant'Anna; a Secção de Taubaté e o Instituto Correcional da Ilha Anchieta; a Casa de Detenção da Capital, as Cadeias Públicas do interior e o Manicômio Judiciário. A criação do Departamento de Presídios foi um importante passo no processo de centralização da administração penitenciária (JESUS FILHO, 2017, p. 40).

Em 1952, ocorreu a maior rebelião penitenciária da história do estado de São Paulo até o massacre do Carandiru, na Ilha Anchieta. Lá estavam alocados 453 dos presos mais perigosos do estado, tendo em vista que se tratava de um presídio de segurança máxima, vigiados por cinquenta guardas. A ação foi planejada por Álvaro da Conceição Carvalho Farto, alcunhado de "Portuga", que chegou a pedir para ir para o isolamento, alegando estar sendo "ameaçado" por outros presos, apenas para ter mais tranquilidade para estudar os detalhes da ação (FERREIRA, 2012, p. 181).

Na manhã de 20 de junho de 1952, cerca de 80 prisioneiros da Ilha Anchieta, que catavam lenha sob a vigilância de seis guardas armados, rebelaram-se. Atacaram os agentes a pauladas e se apossaram de suas armas. Em seguida, tomaram o quartel e a sede da colônia e dividiram-se em dois grupos: um foi para o presídio para libertar os demais presos e outro se dirigiu para a casa do diretor e do comandante para prendê-los. Trocaram tiros com os guardas e com o diretor até que este foi 
capturado pelos rebeldes. 0 diretor, outros funcionários e os guardas foram trancados nas celas (SALLA, 2015, p. 637-638).

Os presos, antes de fugirem, direcionaram sua ira para o responsável pela disciplina na Ilha, Portugal Souza Pacheco. Ele teria sido morto por China Show, um dos líderes da revolta, juntamente com outro preso, conhecido por José Soldado (DIAS, 1984, p. 62). As execuções foram de funcionários que eram tidos como cruéis, que os desrespeitavam. Além disso, destruíram boa parte das dependências do presídio e colocaram fogo em arquivos, móveis e roupas. No entanto, os presos não atacaram as cem mulheres e cerca de duzentas crianças moradoras da ilha (SALLA, 2015, p. 638).

A retomada da ilha começou no final da noite de 20 de junho, quando alguns policiais civis desembarcaram ali. Na manhã seguinte, chegaram os policiais da Força Pública. Os presos que não fugiram não opuseram qualquer reação à ação policial (DIAS, 1984, pp. 81-84).

Não se pode analisar o acontecido na Ilha Anchieta independentemente da situação geral do sistema prisional paulista na época. A manutenção da disciplina na Penitenciária do Estado era mantida por dois meios. 0 primeiro eram os castigos ilegais, como o uso de câmaras escuras feitas de cimento e frias, nas quais os infratores são presos sem roupas e com alimentação controlada. 0 outro era livrar-se dos presos incômodos mandando-os para a Ilha Anchieta (SALLA, 2015, p. 641).

Na Casa de Detenção, em Bom Retiro, que ainda era utilizada, a situação também era deplorável. Instalações inadequadas, onde havia apenas acomodações para trezentas pessoas, alojavam-se até mil e duzentas. Cubículos recebiam vinte ou trinta. Por falta de espaço, chegavam dois detentos a ocupar uma só cama. Havia mistura de presos provisórios com condenados. Havia completa ausência de vigilância em torno dos presos, que comercializavam e consumiam bebidas e entorpecentes e vendem lugares na ala onde as acomodações são aceitáveis, e, já que os próprios presos participam ativamente da administração, fazem a correspondência ou anotações nos boletins, tudo ali gira em função do prestígio pessoal dos mesmos. Não havia uma área de visitas adequada e, por isso, entravam clandestinamente, por ocasião das visitas, aguardente, maconha, cartas para jogos, instrumentos para fugas (SALLA, 2015, p. 645).

Já em relação ao Manicômio Judiciário, a primeira observação era a necessidade de reformas no prédio para reparar os danos causados por um incêndio em 1948 e que até então não haviam sido providenciadas, bem como a precariedade do pessoal no estabelecimento (SALLA, 2015, p. 645).

Para a maior parte da população, que desconhecia as mazelas das prisões do estado e ainda nutria a ilusão de que São Paulo construía e mantinha instituições modelares de controle social, a primeira fuga na Penitenciária do Estado, ocorrida 
em 29 de outubro de 1951, bem como o acontecido na Ilha Anchieta, foi uma surpresa. A fuga trazia à tona práticas de corrupção e mau funcionamento que só os mais atentos observadores tinham conhecimento, mesmo dentro do governo (SALLA, 2015, p. 642).

Em consequência do acontecimento, a unidade prisional na Ilha Anchieta é fechada, e seus detentos transferidos para Taubaté e Tremembé, bem como de inauguração de novas unidades no Vale, em Carandiru e no interior, o que será discutido logo a seguir.

Com o aumento da população carcerária masculina, o Governo de São Paulo foi obrigado a criar novas vagas prisionais, ensejando a ampliação do "Complexo Carandiru". Essa era a realidade em todo o estado, mas o governo não estava fazendo o suficiente para suprir a demanda. Na tabela a seguir, se discrimina o número de novas vagas adicionadas ao sistema por governador, de 1947 a 1994.

Tabela 1 - Novas Vagas no Sistema Carcerário

\begin{tabular}{cc}
\hline Governo & Número de Vagas \\
\hline Pré-1947 & 21.902 \\
Adhemar de Barros (1947-1951) & 0 \\
Lucas Garcez (1951-1953) & 0 \\
Jânio Quadros (1955-1959) & 2.898 \\
Carvalho Pinto (1959-1963) & 000 \\
Adhemar de Barros (1963-1966) & 0 \\
Laudo Natel (1966-1967) & 450 \\
Abreu Sodré (1967-1971) & 251 \\
Laudo Natel (1971-1975) & 1.974 \\
Paulo Egydio (1975-1979) & 0 \\
Paulo Maluf (1979-1982) & 0 \\
José Maria Marin (1982-1983) & 1.480 \\
Franco Montoro (1983-1987) & 8.884 \\
Orestes Quércia (1987-1991) & 2.333 \\
Fleury Filho (1991-1994) & 18.770 \\
\hline Total &
\end{tabular}

Fonte: RODRIGUES, 2011, p. 24-25

Neste sentido, em 1954 teve início a construção de um novo estabelecimento anexo ao Carandiru inaugurado em 1956, no Governo Jânio Quadros. O novo estabelecimento destinava-se ao recolhimento de presos provisórios e dos que cumpriam pena de detenção (RODRIGUES, 2011, p. 14).

Em 1955, junto a essas vagas, o estado, sob a tutela do penitenciarista Cândido Mendes, também inaugurou unidades penitenciárias em Bauru, Itapetininga e São José do Rio Preto em campi de escolas técnicas, timidamente iniciando uma interiorização da oferta de vagas no semiaberto. A unidade de Itapetininga, por sofrer 
severa oposição da população local, voltou a ser escola técnica em 1968 (ANDRADE, 2011, p. 2).

Estas unidades eram de modelo agrícola, em que o preso trabalhava no campo, e eram vistas, assim como Carandiru em 1920, como modelos de estrutura correcional. Todavia, também como Carandiru, não tardaria até essas unidades também sofrerem com superlotação e abusos de toda a sorte contra a população carcerária (SALLA, 2000, p. 213).

Além dessas, houve a fundação da Casa de Custódia e Tratamento de Taubaté, onde, em 1993, oito presos fundariam o Primeiro Comando da Capital, bem como do Instituto de Reeducação de Tremembé (SALLA, 2015, p. 650).

Ainda sobre a Casa de Custódia de Taubaté, que havia entrado em funcionamento em 1955, tornou-se, em agosto de 1961, alvo de mais uma tentativa de fuga seguida de uma rebelião com fim trágico: deixou um saldo de mais de 40 mortos entre os presos (MONTEIRO; OLIVEIRA, 2005, p. 105).

Ela teria sido liderada por Anorelino Soares Filho, conhecido como Capitão Sujeira, um dos principais envolvidos nos acontecimentos do levante da Ilha Anchieta, juntamente com outros presos que também haviam participado daquela rebelião, como Caveirinha, Zé da Silva, Meia-Noite e Alemão. A Casa de Custódia possuía, na época da rebelião, 231 presos, e ficou bastante destruída. Quase todas as vítimas morreram carbonizadas, pois eram presos de um pavilhão que ficou trancado enquanto havia sido ateado fogo a colchões e móveis no seu interior (SALLA, 2015, p. 651).

As causas da rebelião teriam sido o uso liberal de eletrochoque e medicação para controle do comportamento dos presos, bem como outras formas generalizadas de maus tratos aos detentos. A ideia era se amotinar para possibilitar uma fuga em massa (MONTEIRO; OLIVEIRA, 2005, 157-160).

Ao contrário do que ocorrera com o Estado Novo, o Golpe de 1964 não alterou essencialmente as estruturas administrativas dos estados. Os governadores não eram mais eleitos diretamente a partir do Ato Institucional no 3, e o governo federal poderia cassá-los a qualquer tempo (como o fez em São Paulo contra Adhemar de Barros, em 1966), mas os estados continuavam desfrutando de autonomia e prosseguiram com seus projetos internos em todas as áreas, contanto que não se contrariasse o interesse dos militares.

Em termos de segurança pública não foi diferente, em que pese as políticas e a ideologia do regime. A guerra contra o "inimigo interno", como era definida pelo governo militar, significou uma intensificação das atividades policiais, bem como a sua classificação como "forças de segurança auxiliares". Data dessa época uma articulação, cada vez mais transparente e sempre crescente, entre o funcionamento do aparelho policial e do aparelho penitenciário (FISCHER; ADORNO, 1987, p. 70). 
Ao longo da década de 1960 foram entregues os demais pavilhões que compunham o Complexo do Carandiru na época de sua implosão, o que significou um aumento razoável de vagas. Isso não significou nenhuma reversão nas tendências do presídio, já que o número de presos não parou de crescer. Na mesma década as celas individuais foram transformadas em coletivas, mas ainda assim a Casa de Detenção não suportou a demanda (RODRIGUES, 2011, p. 14).

Isso se deve porque o governo, a partir de 1964, endureceu bastante a legislação criminal no país, extinguiu a liberdade condicional e dificultou a progressão de pena. Houve um direcionamento de recursos para o reaparelhamento e a modernização da Polícia Militar, com o objetivo de, não apenas à repressão às organizações políticas de oposição, mas também ao combate da criminalidade (FISCHER; ADORNO, 1987, p. 70).

A Penitenciária do Estado foi transformada, também, em presídio para cumprimento de todo tipo de pena, passando a recolher presos de todas as espécies, desde autores de crimes de pouco potencial ofensivo até presos com alto grau de periculosidade, bem como prisioneiros políticos (RODRIGUES, 2011, p. 14).

Na busca de equacionar o problema suscitado, escolheu-se uma solução infeliz: decidiu-se que os Distritos Policiais da Capital passariam a abrigar presos, e não apenas presos provisórios, mas, também, sentenciados em cumprimento de penas (RODRIGUES, 2011, p. 14).

Isso é um problema na medida em que as instalações da Polícia Civil não são adequadas ao acondicionamento permanente de pessoas. São instalações simples, projetadas para conter um número pequeno de pessoas apenas pelo tempo necessário para lavrar os autos de prisão e demais procedimentos burocráticos.

Em função disso, os presos em cumprimento de pena se acumulam e se misturam com os provisórios, em condições muito aquém das necessárias para seu acondicionamento em mínimas condições de salubridade.

Também na década de 1960, em 1961, foi fundado o primeiro presídio do Oeste Paulista. Instalado num antigo quartel e regimento da Polícia Militar, a Penitenciária Regional de Presidente Venceslau foi projetada para receber todos os condenados provenientes de municípios do interior oeste do estado, aqueles que residissem mais distante da capital e do Vale do Paraíba (JESUS FILHO, 2017, p. 42).

A situação permaneceu estável, tanto em questões administrativas como em questões físicas, nos dois governos de Laudo Natel e no governo de Abreu Sodré. A próxima onda de mudanças no sistema penitenciário aconteceu a partir de 1976, no governo de Paulo Egydio. 
Em 1976, o estado de São Paulo tinha uma população encarcerada de 17.192 pessoas, sendo 9.392 presos na rede da Secretaria da Justiça e os demais 7.800 nas cadeias públicas (OLIVEIRA, 1978, p. 28). 0 governo do estado, admitindo a superlotação em Carandiru (cuja capacidade era de 2200 presos e já continha 6.553 presos em 1977) e as condições prisionais de várias cadeias, constrói e inaugura seis novas unidades prisionais, em Araraquara, Avaré, Pirajuí, Itirapina, São Vicente e Sorocaba, e cria também uma comissão para apresentar soluções ao problema do crescente encarceramento (JESUS FILHO, 2017, p. 45).

Nos últimos dias de governo Paulo Egydio, foi criada também a Coordenadoria dos Estabelecimentos Penitenciários do Estado de São Paulo (Coespe). A ideia é desenvolver a parte burocrática da aplicação da justiça, de modo a reduzir o arbítrio dos diretores, melhorar as condições de vida dos presos comuns e diminuir a incidência de motins e rebeliões nos estabelecimentos (JESUS FILHO, 2017, p. 45-47).

Essas reformas ocorreram num ambiente paradoxal do governo Paulo Egydio Martins. Enquanto o secretário de segurança pública, Erasmo Dias, reprimia severamente os movimentos sociais e o movimento estudantil, enquanto Manuel Pedro Pimentel, secretário de justiça, promoveu todas essas reformas em permanente diálogo com a sociedade civil. Sua proposta era tornar as prisões abertas à sociedade (JESUS FILHO, 2017, p. 46).

Franco Montoro, primeiro governador eleito por voto popular desde 1964, impulsionou reformas democráticas ao mesmo tempo em que colocou em prática mecanismos de controle da ação policial e aperfeiçoamento da gestão penitenciária, buscando conciliar as exigências de segurança pública com a preservação de direitos humanos (FISCHER; ADORNO, 1989, p. 48).

Depois dos governos Maluf e Marin, segundo a Comissão Teotônio Vilela, havia 11.276 presos nos estabelecimentos penais e outros 12.815 nas delegacias e cadeias da capital e do interior, num total de 24.091 presos. A população carcerária no estado havia crescido cerca de $40 \%$ entre o governo Paulo Egydio e Franco Montoro, sem que novas unidades prisionais tivessem sido criadas (SALLA, 2007, p. 74).

O sistema penitenciário atravessou, então, um período de grande turbulência, que se expressava principalmente na eclosão de rebeliões e tentativas de fuga em massa. Para enfrentar essa crise, o governador nomeou o advogado José Carlos Dias, conhecido por sua atuação contra a ditadura, para a Secretaria de Justiça (SALLA, 2007, p. 74-76).

O secretário elegeu a questão penitenciária como objeto prioritário, rompendo com as práticas autoritárias do período ditatorial e, para tanto, deu início a programas voltados à preservação dos direitos humanos dos presos, aliados a uma política de assistência judiciária, escolarização e profissionalização (JESUS FILHO, 2017, p. 48). 
Em contrapartida, o governo também criou o Piranhão, um regime disciplinar mais severo em um dos anexos da Casa de Detenção de Taubaté. Lá, presos permaneciam por 23 horas em total isolamento, sem atividade coletiva, sem banho de sol, sob rígida disciplina e restrições para o contato com o mundo exterior (JESUS FILHO, 2017, p. 48-49).

A ideia, apesar de consistir numa melhora em relação ao regime militar, não pode ser considerado uma humanização completa. 0 caráter moderado das propostas implementadas nessa gestão indica que nunca se chegou a questionar as funções de violência e punição, mas apenas procurou-se executá-las através de métodos mais especializados e, portanto, menos violentos (GÓES, 2004, p. 221).

Tal moderação era decorrente da ausência de coesão política do governo estadual em torno da questão penitenciária, mas acabou por dificultar o envolvimento efetivo das entidades de defesa dos direitos humanos, muito atuantes na época, em favor dessa política carcerária (GÓES, 2004, p. 222).

Assim, pressões de forças tanto externas quanto internas, mídia impressa, juízes, agentes penitenciários e membros do próprio PMDB, partido de Montoro, resistentes às propostas de humanização do tratamento aos presos, forçaram a saída de José Carlos Dias do governo e uma reversão severa às políticas de humanização (VIEIRA, 2005, p. 114).

Para as eleições seguintes, ganharam força no interior do PMDB aqueles que adotavam uma política de endurecimento penal. Orestes Quércia foi eleito e, juntamente com seu secretário de segurança pública à época e futuro governador Luis Antônio Fleury Filho, lançaram um pacote de securitização (JESUS FILHO, 2017, p. 49).

Dias (2011) ressalta que o aumento e a transformação do perfil da criminalidade urbana provocaram um forte impacto nas polícias, encarregadas de contê-la, em especial uma enorme pressão que tendeu a ser transmitida em cadeia para as agências judiciárias e penitenciárias.

Com Quércia como governador, o sistema prisional conhece seu primeiro período de acelerada expansão e interiorização, principalmente em direção ao Oeste Paulista, do sistema penitenciário. Somente durante o seu governo, 30 novas unidades prisionais foram inauguradas (JESUS FILHO, 2017, p. 49).

Outro elemento importante que influenciaria os rumos da questão penitenciária na década de 1990 foi o incremento da população penitenciária, estimulado por um movimento da sociedade em favor do endurecimento das penas, do discurso da insegurança e da guerra contra as drogas (JESUS FILHO, 2017, p. 52).

Todos esses desenvolvimentos do início do processo de democratização confluem para o mesmo ponto: a reconhecida incapacidade e incompetência do poder públi- 
co em gerenciar amplas massas carcerárias, constituindo uma política efetivamente coordenadora da execução penal (ADORNO, 1991, p. 68).

Tal acabou por se evidenciar no pior desastre da história da administração penitenciária brasileira: o Massacre do Carandiru. Com as causas já apresentadas, a seguir, falaremos sobre o evento em si e suas consequências.

\section{O Massacre do Carandiru}

A Casa de Detenção, durante toda a década de 1990, continuou com aumento diário de presos, sofrendo deterioração das instalações físicas, elétricas e hidráulicas, com funcionários mal remunerados e a violência crescente, sem receber necessárias obras de manutenção e reforma (PIETÁ; PEREIRA, 1993, p. 41).

As condições de funcionamento da penitenciária desrespeitavam a legislação e apresentavam distância imensa dos padrões indicados pelas recomendações. 0 estabelecimento representava, na verdade, o que de mais anacrônico, de mais perverso uma sociedade poderia criar e manter (PIETÁ; PEREIRA, 1993, p. 41).

Como é de se esperar em tais condições, a Casa de Detenção foi palco de diversas rebeliões e outros conflitos, em geral culminando com violência e mortes de detentos e funcionários. A mais consequente delas foi a de outubro de 1992, o "Massacre do Carandiru", que culminou com 110 internos mortos, com sinais claros de execução (RODRIGUES, 2011, p. 15-19).

Na manhã de 2 de outubro de 1992, no Pátio do Pavilhão 9 da Casa de Detenção, houve uma briga entre os presos Antônio Luiz do Nascimento, vulgo "Barba", e Luiz Tavares de Azevedo, vulgo "Coelho", possivelmente por desentendimentos anteriores. 0 que deveria ser apenas mais um desentendimento entre detentos acabou escalonado: presos em grande número entraram em violento combate (RODRIGUES, 2011, p. 17).

Do momento do início do embate, havia acabado de terminar um jogo de futebol entre detentos e grande era o contingente solto no pátio. Centenas de presos teriam recebido ordem para retornar às suas celas, quando se encontram com as partes em conflito. A maioria viu-se no meio da confusão e tentavam se defender (RODRIGUES, 2011, p. 17-18).

Ao perceberem que haviam perdido totalmente o controle os agentes penitenciários bateram em retirada, afugentados pelos presos (RODRIGUES, 2011, p. 17).

Autorizados pelo Secretário da Segurança Pública, Pedro Franco de Campos, Policiais Militares dos $1^{\circ}$, $2^{\circ}$ e $3^{\circ}$ Batalhões de Choque, do Comando de Operações Especiais e do Grupamento de Ações Táticas Especiais, sob comando do Coronel Ubiratan Guimarães, invadiram o Pavilhão 9, armados de fuzis, metralhadoras, pis- 
tolas e revólveres. A ação foi rápida, sangrenta e implacável (RODRIGUES, 2011, p. 18-19).

O caos do sistema de administração da justiça paulista não pôde mais ser ignorado. 0 elevado número de mortes num acontecimento comparativamente pequeno evidenciou o recrudescimento e a violência da Polícia Militar, que sempre ocorreu, mas que sempre foi acobertado (e mesmo incentivado) pela ditadura, mas que agora era incompatível com a nova ordem política do país (MESQUITA NETO, 1999, p. 129-130).

O Massacre do Carandiru foi o cume da política intervencionista e violenta predominante na segurança pública nos períodos dos governos Quércia e Fleury. Era um posicionamento muito agressivo no combate ao crime e no enfrentamento das revoltas de detentos, como, por exemplo, a folclórica rebelião de 1986 em Presidente Venceslau ${ }^{1}$, dentro de um padrão de baixa preocupação com negociações, de atuações marcadas pela arbitrariedade e pelo abuso de poder (SALLA, 2007, p. 78).

Ademais, era notável agora que o sistema penitenciário estava necessitado de reforma. Muitas as propostas foram feitas, acordos com o governo federal e com a comunidade internacional foram firmados. De modo a administrar essas mudanças, foi criada a Secretaria de Administração Penitenciária, a primeira secretaria de estado a cuidar especificamente da matéria (RODRIGUES, 2011, p. 20-21).

A primeira ação foi a desativação de Carandiru. A proposta agora era de presídios de pequeno porte, espalhados por todo o estado, com estrita divisão relacionada ao tipo de crime cometido e à origem geográfica do preso. Presos do interior deveriam cumprir pena nas suas regiões administrativas de origem, enquanto os da capital eram distribuídos pelo estado, tendo em vista que a cidade não tinha vagas o suficiente para mantê-los.

A região metropolitana conta, hoje, com oito penitenciárias (três em Franco da Rocha, duas em Guarulhos, uma masculina em Parelheiros e duas femininas na região do Carandiru), sendo que Franco da Rocha I é para progressão de regime e Guarulhos I é para o semi-aberto. Existem ainda dezessete centros de detenção provisória e três centros de progressão penitenciária.

O tamanho da população carcerária na Casa de Detenção era alvo de críticas desde a década de 1980, quando se recomendava que nenhuma instituição abrigasse mais que 500 presos, enquanto Carandiru, no auge, abrigava mais de oito mil (RODRIGUES, 2011, p. 14).

Os onze presídios e suas destinações são discriminadas na tabela abaixo:

\footnotetext{
${ }^{1}$ Nessa rebelião, onze presos foram mortos a pauladas pela Polícia Militar. Pela localização do presídio, na região central da cidade, os munícipes assistiram à ação das forças de segurança. 0 evento ainda está presente na memória coletiva da cidade, e a ele são comparadas a rebelião de 2005, em que cinco presos foram decapitados e suas cabeças expostas na muralha da penitenciária, e a tentativa de fuga em fevereiro de 2019.
} 
Tabela 2 - Presídios e Presos Designados

\begin{tabular}{|c|c|c|}
\hline Presídio & Regional & Designação \\
\hline Centro de Progressão & & Os condenados a cum- \\
\hline $\begin{array}{l}\text { Penitenciária de } \begin{array}{l}\text { Pa- } \\
\text { caembu }\end{array}\end{array}$ & Croeste & $\begin{array}{l}\text { prir penas no regime } \\
\text { semiaberto }\end{array}$ \\
\hline Centro de Progressão & & Os condenados a cum- \\
\hline $\begin{array}{l}\text { Penitenciária de Valpa- } \\
\text { raíso }\end{array}$ & Croeste & $\begin{array}{l}\text { prir penas no regime } \\
\text { semiaberto }\end{array}$ \\
\hline $\begin{array}{l}\text { Penitenciária de Drace- } \\
\text { na }\end{array}$ & Croeste & $\begin{array}{l}\text { Condenados pelos cri- } \\
\text { mes de estelionato, re- } \\
\text { ceptação e porte ilegal } \\
\text { de armas }\end{array}$ \\
\hline Penitenciária de Lavínia & Croeste & $\begin{array}{l}\text { Condenados por tráfi- } \\
\text { co de entorpecentes, } \\
\text { primários, sem outros } \\
\text { crimes }\end{array}$ \\
\hline $\begin{array}{l}\text { Penitenciária de Para- } \\
\text { guaçu Paulista }\end{array}$ & Croeste & $\begin{array}{l}\text { Condenados por homi- } \\
\text { cídio, primários, sem } \\
\text { outros crimes }\end{array}$ \\
\hline Penitenciária I de Potim & Corevale & $\begin{array}{l}\text { Presos moradores } \\
\text { e/ou com familiares } \\
\text { na região do Vale do } \\
\text { Paraíba }\end{array}$ \\
\hline $\begin{array}{l}\text { Penitenciária II de Po- } \\
\text { tim }\end{array}$ & Corevale & $\begin{array}{l}\text { Autores de crime de } \\
\text { roubo, primários }\end{array}$ \\
\hline $\begin{array}{l}\text { Penitenciária de Oswal- } \\
\text { do Cruz }\end{array}$ & Croeste & $\begin{array}{l}\text { Condenados por estu- } \\
\text { pro e atentado violen- } \\
\text { to ao pudor, sem con- } \\
\text { denações por outros } \\
\text { crimes }\end{array}$ \\
\hline $\begin{array}{l}\text { Penitenciária de Praci- } \\
\text { nha }\end{array}$ & Croeste & $\begin{array}{l}\text { Condenados por tráfi- } \\
\text { co de entorpecentes, } \\
\text { primários }\end{array}$ \\
\hline $\begin{array}{l}\text { Penitenciária I de Serra } \\
\text { Azul }\end{array}$ & Cronorte & $\begin{array}{l}\text { Presos moradores } \\
\text { e/ou com família na } \\
\text { região de Ribeirão } \\
\text { Preto }\end{array}$ \\
\hline $\begin{array}{l}\text { Penitenciária II de Serra } \\
\text { Azul }\end{array}$ & Cronorte & $\begin{array}{l}\text { Condenados por estu- } \\
\text { pro e atentado violen- } \\
\text { to ao pudor, com con- } \\
\text { denações por outros } \\
\text { crimes }\end{array}$ \\
\hline
\end{tabular}

Fonte: RODRIGUES, 2011, p. 22

Além disso, foram feitas importantes modificações legais e administrativas. A Lei no 9.299 de 1996 modificou a competência da Justiça Militar e a natureza do crime de homicídio doloso praticado por militar contra civil, considerado agora um crime comum, não militar, processado pela justiça comum. A lei foi motivada num contex- 
to de desgaste da Polícia Militar nos anos que se sucederam à chacina (JESUS FILHO, 2017, p. 52-53).

Além disso, até o Massacre do Carandiru, o diretor realizava transferências de presos sem necessidade de autorização judicial ou de um superior. De fato, uma das versões para explicar as causas do Massacre do Carandiru seria justamente uma transferência autorizada pelo então diretor, Ismael Pedrosa, de presos do Centro de Observação Criminológica (a área de triagem do presídio) para o Pavilhão 9. Esses presos eram desafetos dos presos do Pavilhão 9 e teriam dificultado e inviabilizado as negociações entre presos e direção durante a rebelião, forçando a entrada da Polícia Militar (JESUS FILHO, 2017, p. 53).

Cinco dias após o incidente, em resposta direta, o executivo estadual encaminha à Assembleia Legislativa proposta para criação da Secretaria de Administração Penitenciária (SAP) do estado de São Paulo. A SAP foi criada em janeiro de 1993, num momento de mudança profunda nas políticas de segurança, distanciando a administração penitenciária do modelo dos demais estados (JESUS FILHO, 2017, p. 53).

A instituição de uma secretaria independente permitiu aos gestores se concentrarem no aperfeiçoamento administrativo. Dezenas de atos normativos foram expedidos para regular toda a rotina penitenciária. As mudanças eram visíveis em termos gerenciais, observadas especialmente no estabelecimento de protocolos, padronização de rotinas e redução do arbítrio no trato tanto com os detentos quanto com os funcionários e visitantes. Igualmente, particularmente a partir de 2000, medidas humanizadoras e de maior transparência da gestão penitenciária foram acionadas (JESUS FILHO, 2017, p. 57).

Essa mudança, devida certamente ao vexame e à barbárie ocorrida em Carandiru, passa a permear a questão penitenciária no estado de São Paulo até as eleições de 2018. A seguir, trataremos do sistema prisional paulista na história recente.

\section{Crime Organizado, Secretaria da Administração Penitenciária e o}

\section{Século XXI}

A primeira ordem da SAP ao ser fundada, de modo a sanear a oferta de vagas no sistema prisional e diminuir a superlotação, era de construir novos presídios. Como já foi dito, as novas unidades seriam de tamanhos menores, comportando até mil presos cada. Dado a ausência de terrenos disponíveis ao redor da capital, e de modo a concretizar o plano antigo de permitir que detentos cumpram penas nas suas regiões de origem, praticamente todas as novas penitenciárias foram e são construídas no interior.

Em 1976, havia apenas dez presídios no então Departamento dos Institutos Penais do Estado (DIPE) e de uma população total de 9.392 presos sob a custódia da Secretaria da Justiça. Somente a Casa de Detenção de São Paulo possuía 6.473, sendo 
5.333 já condenados. Uma vez que a Penitenciária do Estado concentrava cerca de 1.200 presos, era responsável por 80\% da população do DIPE (OLIVEIRA, 1978, p. 118).

Quando Franco Montoro assumiu o governo de São Paulo em 1983, havia 14 unidades em funcionamento e um total de cerca de 10 mil presos, e a Casa de Detenção ainda respondia por algo em torno de 60\% desse total (SALLA, 2007, p. 75). Para o novo milênio, em 1997, a gestão Mário Covas anunciava a construção simultânea de vinte e sete unidades, a maioria delas em várias partes do interior (GÓES, 2004, p. 220)

Mais além: o plano de expansão da estrutura prisional paulista é parte importante do projeto de interiorização do investimento do governo estadual, concebido e amplamente praticado pelos governos do PSDB.

A maioria dos estabelecimentos é construída em municípios pequenos do Oeste Paulista, em geral deficientes de qualquer indústria além da agropecuária, cujos prefeitos disputam acirradamente os contratos de instalação. Só na década de 1990, por exemplo, foram construídos dez presídios nessa região (GÓES, 2004, p. 220).

O governador sucessor de Fleury, Mário Covas, que assumiu em 1995, foi o responsável pela retomada de vários compromissos de direitos humanos na área da segurança pública. Ficou evidente a disposição do governo, por exemplo, de reduzir as mortes provocadas por policiais, que de um patamar de 1.140 em $1991 \mathrm{e}$ 1.470 em 1992 caíram para 249 em 1996 e se mantiveram estáveis em 253 casos em 1997 (CALDEIRA, 2000, p.161).

0 governo enfrentou, no entanto, dificuldades logo no início da sua gestão. 0 governo teve que convencer, a duras penas, a opinião pública de que iniciava um novo estilo de tratar com as rebeliões, em que a negociação seria a forma privilegiada. 0 governo deu início a uma praxe, a partir de 1995, da constituição de grupos de negociação que incluíam inclusive representantes da sociedade civil. Mesmo assim, a longa rebelião ocorrida na Penitenciária I de Tremembé em 26 de março de 1995, uma das mais longas da história do sistema penitenciário brasileiro, com 130 horas, chegou ao fim com um total de dois presos mortos, dois funcionários feridos e dois policiais feridos (SALLA, 2007, p. 79-80).

O governo além das dificuldades para inaugurar um outro tipo de intervenção nas rebeliões, passaria a enfrentar a ação de grupos criminosos organizados no interior das penitenciárias. Em Hortolândia, o governo foi criticado por parte da imprensa quanto ao atendimento às exigências de transferência (SALLA, 2007, p. 80).

Na rebelião em Tremembé, entre as reivindicações voltadas para viabilizar a fuga do presídio, uma outra demanda dos presos era a desativação do Piranhão. Embora o governo negasse a existência de grupos criminosos organizados, suas lideranças 
eram frequentemente isoladas lá e diversas rebeliões ocorriam nas demais unidades prisionais manifestando o descontentamento dos presos com aquele regime (SALLA, 2007, p. 80).

O Primeiro Comando da Capital, o PCC, surgiu em agosto de 1993 em Taubaté como reação à violência institucional das intervenções policiais no Massacre do Carandiru e pela morte de dezoito presos por asfixia no $42^{\circ}$ Distrito Policial de São Paulo em 1989, aliados às transferências para o Piranhão e à omissão do Estado em atender aos direitos básicos da população carcerária (DIAS, 2011, p. 111).

Em 27 de maio de 1997, sai a primeira menção na imprensa do PCC. A Folha de São Paulo reportou que um preso enviou uma carta a Confederação Nacional dos Bispos do Brasil, relatando os valores e objetivos do grupo. 0 governo do estado negou sua existência, dispensando-os como produto de Carandiru e afirmando que colapsaria assim que o presídio fosse desativado. Essa seria a versão oficial durante toda a década de 1990 (SALLA, 2007, p. 80-81).

A expansão da organização foi simbólica, marcada por solidariedade e união entre presos, cuja característica comum é a pertença à mesma camada social: jovens negros provenientes das periferias, com baixa escolaridade e mínimo acesso aos bens da sociedade. 0 sinal de que o PCC crescia nesse período é o aumento do número de fugas e resgates, frutos de organização coletiva e uso de armas e equipamentos sofisticados (DIAS, 2011, p. 116).

A própria desativação de Carandiru foi um assunto controverso. Durante todo o governo Mário Covas, a intenção sempre era desativá-lo, mas nunca foi tomada nenhuma providência nesse sentido. Ao contrário, o governo reformou e aparelhou o presídio, alegando que a demanda por vagas não permitia que sete mil leitos no complexo fossem perdidos (SALLA, 2007, p. 81-82).

Em fevereiro de 2001, quando Mário Covas já estava afastado por complicações relacionadas a um câncer e Geraldo Alckmin administrava o estado, ocorreu uma rebelião coordenada em vinte e nove penitenciárias em todas as regionais, com o comando das ações sediado em Carandiru, nas mãos do PCC. A ação cobrava a transferência de volta do Piranhão de líderes da organização, bem como a desativação de Carandiru, em função do abuso de seus direitos que eram frequentes ali (SALLA, 2007, p. 82).

O Piranhão foi desativado, junto com todas as unidades prisionais permanentes em Taubaté, mas o sistema foi reformulado e instalado em Presidente Bernardes (no Oeste Paulista) e em Avaré (na região central). Nasce, então, o Regime Disciplinar Diferenciado (RDD).

Em 12 de maio de 2006, o PCC atacou novamente em represália ao RDD e iniciou uma rebelião em 79 unidades prisionais do Estado de São Paulo. Simultaneamente, ocorreram nas ruas da capital e de cidades importantes do interior vários ataques 
a agentes públicos, veículos, edifícios e delegacias de polícia. Dezenas de agentes públicos foram assassinados, especialmente policiais militares e agentes penitenciários de baixo escalão (JESUS FILHO, 2017, p. 60).

Em represália, a Polícia Militar, despreparada e irracional, saiu às ruas assassinando civis sob o argumento de que eram suspeitos de integrarem o PCC. As folgas e férias dos policiais foram canceladas e todo o efetivo saiu às ruas. Instalou-se um clima de guerra (JESUS FILHO, 2017, p. 60).

O saldo foi de 493 civis e 59 agentes públicos assassinados durante a semana de 12 a 19 de maio de 2006. Além das mortes, um número indefinido de pessoas foi dado como desaparecidos. 0 auge dos assassinatos ocorreu no dia 17 de maio, quando 117 corpos deram entrada no Instituto Médico Legal da capital (JESUS FILHO, 2017, p. 60).

Esse evento instalou uma crise institucional no governo de São Paulo. 0 então secretário de segurança pública e o da administração penitenciária mantinham sérias divergências que se tornaram públicas. No conflito entre os dois, o governador Cláudio Lembo preferiu manter a SSP e demitir o líder da SAP (JESUS FILHO, 2017, p. 60).

Desde então, nos governos de José Serra e Geraldo Alckmin, cobrindo dezesseis anos, entre 2007 e 2018, não houve mais grandes rebeliões nos presídios do estado, e a política de segurança pública e administração penitenciária.

\section{Conclusão}

As eleições de 2018, em todos os níveis de governo, em todas as unidades federativas do país, foram uma grande revolução nas agendas e nas prioridades dos eleitores. Há uma tendência de política conservadora e securitização de todas as áreas da administração pública.

É de se esperar que o mesmo aconteça com a Administração Penitenciária, mas mesmo que nenhuma grande revolução seja feita nessa pasta, especificamente, como pôde ser observado, o recrudescimento da política penal engrossa o contingente prisional, o que gera tensões relacionadas à superlotação.

Há também a proposta privatizante do governador João Dória, algo que, na gestão penitenciária, sofreu oposição histórica da direção do PSDB em São Paulo, que foi grandemente desmoralizada nas últimas eleições. Consequentemente, a pauta passou a ser mais aceita entre a elite administrativa do estado.

O objetivo deste trabalho é fomentar bases históricas para a reflexão dos problemas da administração da justiça, tanto em São Paulo como no resto do país e das 
Américas, muitos deles com origens em comportamentos presentes quase que desde sempre nas reflexões das execuções penais na nossa sociedade.

Assim, não se busca nem encerrar, nem fundar uma linha de pensamento aqui, mas tão somente fomentar novas reflexões sobre o tema, tão severamente desprezado nas discussões sobre segurança pública e direito administrativo.

\section{Referências bibliográficas}

ADORNO, Sérgio. Sistema Penitenciário no Brasil: Problemas e Desafios. Revista USP, n. 9, p. 65-78. São Paulo: Editora USP, 1991.

ANDRADE, Bruna Soares Angotti Batista de. Entre as Leis da Ciência, do Estado e de Deus: 0 surgimento dos presídios femininos no Brasil. 2011. Tese (Mestrado em Antropologia Social) - Faculdade de Filosofia, Letras e Ciências Humanas, Universidade de São Paulo.

BELMONTE, Benedito Carneiro Bastos. No Tempo dos Bandeirantes. 2a Ed. São Paulo: Companhia Editora Nacional, 1939.

CALDEIRA, César. Segurança Pública e Política Penitenciária no Rio de Janeiro: estudo do caso do presídio Ary Franco. Revista Rio de Janeiro, no 12, v. 1, pp.11-38. Rio de Janeiro: Universidade Estadual do Rio de Janeiro, 2004.

DIAS, Benedito Nunes. Motim da Ilha. São Paulo: Editora Soma, 1984.

DIAS, Camila Caldeira Nunes. Da Pulverização ao Monopólio da Violência: expansão e consolidação do Primeiro Comando da Capital (PCC) no sistema carcerário paulista. 2011. Tese (Doutorado em Sociologia) - Faculdade de Filosofia, Letras e Ciências Humanas, Universidade de São Paulo.

FERNANDES, Newton. A Falência do Sistema Prisional Brasileiro. 1aㅡ Ed. São Paulo: RG Editores Ltda. 2000.

FERREIRA, Ramiro Dos Santos. Homens de Azul. São Paulo: Clube de Autores. 2012.

FISCHER, Rosa Maria; ADORNO, Sérgio. Análise do Sistema Penitenciário do Estado de São Paulo: o gerenciamento da marginalidade social. São Paulo: Cedec, 1987.

FOUCAULT, Michel. Vigiar e Punir. Lisboa: Leya, 2014.

GÓES, Eda Maria. Transição Política e Cotidiano Penitenciário. História (São Paulo), v. 23, n. 1-2, p. 219-238, 2004.

JESUS FILHO, José de. Administração Penitenciária: o controle da população carcerária a partir da gestão partilhada entre diretores, judiciário e facções. 2017. Tese (Doutorado em Administração Pública e Governo) - Escola de Administração de Empresas de São Paulo, Fundação Getúlio Vargas. 
LETHAL Injection. Intérpretes: John Oliver. Nova Iorque: Avalon Entertainment, 2019. (19 min.), son., color. Série Last Week Tonight. Disponível em: <https://www.youtube.com/watch?v=0lTczPEG8il>. Acesso em: 26 out. 2019.

MESQUITA NETO, Paulo. Violência Policial no Brasil: abordagens teóricas e práticas de controle. Cidadania, Justiça e Violência. Rio de Janeiro: Fundação Getúlio Vargas, p. 129-148, 1999.

MONTEIRO, Lamarque; OLIVEIRA, Samuel Messias de. A Casa de Custódia de Taubaté: Revoluções, rebeliões, berço do PCC. Taubateana, vol. 26. Taubaté: Prefeitura Municipal de Taubaté.

NEVES, Cylaine Maria das. A Vila de São Paulo de Piratininga: fundação e representação. São Paulo: Annablume, 2007.

OLIVEIRA, Marina Marigo Cardoso de. A Religião nos Presídios. São Paulo: Cortez \& Moraes, 1978. v. 2.

PIETÁ, Eloi; PEREIRA, Justino. Pavilhão 9: 0 Massacre do Carandiru. 2ª Ed. São Paulo: Página Aberta, 1993.

RODRIGUES, Nélson. Sistema Prisional Paulista: Transformações e Perspectivas. Revista de Criminologia e Ciências Penitenciárias, v. 1, n. 1, 2011.

SALLA, Fernando. As Prisões de São Paulo: 1822-1940. 1aㅡ Ed. São Paulo: Annablume, 1999.

. Casa de Detenção de São Paulo: Passado e Presente. Revista Brasileira de Ciências Criminais, vol. 8, n. 32. São Paulo: Editora Revista dos Tribunais, 2000.

. De Montoro a Lembo: as políticas penitenciárias em São Paulo. Revista Brasileira de Segurança Pública, vol. 1, ed. 1. São Paulo: Fórum Brasileiro de Segurança Pública, 2007. Disponível em: <https://www.researchgate.net/profile/Fernando_Salla/publication/237718671_De_Monto-

ro_a_Lembo_as_politicas_penitenciarias_em_Sao_Pau-

lo/links/5544c1c20cf24107d396f3dd.pdf\#page=72>. Acesso em: 24 out. 2019.

. Rebelião na Ilha Anchieta em 1952 e a Primeira Grande Crise na Segurança Pública Paulista. Dilemas: Revista de Estudos de Conflito e Controle Social, v. 8, n. 4, p. 633-658, 2015.

VIEIRA, Hermes e SILVA, Oswaldo. História da Polícia Civil de São Paulo. 1aㅡ ed. São Paulo: Companhia Editora Nacional, 1955.

VIEIRA, José Carlos. Democracia e Direitos Humanos no Brasil. São Paulo: Edições Loyola, 2005. 